\title{
Reaching a Consensus: Terminology and Concepts Used in Coordination and Decision-Making Research
}

\author{
Lennart W. Pyritz • Andrew J. King • \\ Cédric Sueur • Claudia Fichtel
}

Received: 17 January 2011 / Accepted: 15 March 2011/Published online: 25 May 2011 (C) The Author(s) 2011. This article is published with open access at Springerlink.com

\begin{abstract}
Research on coordination and decision-making in humans and nonhuman primates has increased considerably throughout the last decade. However, terminology has been used inconsistently, hampering the broader integration of results from different studies. In this short article, we provide a glossary containing the central terms of coordination and decision-making research. The glossary is based on previous definitions that have been critically revised and annotated by the participants of the symposium "Where next? Coordination and decision-making in primate groups" at the XXIIIth Congress of the International Primatological Society (IPS) in Kyoto, Japan. We discuss a number of conceptual and methodological issues and highlight consequences for their implementation. In summary, we recommend that future studies on coordination and decision-making in animal groups do not use the terms "combined decision" and "democratic/despotic decision-making." This will avoid ambiguity as well as anthropocentric connotations. Further, we demonstrate the importance of 1) taxon-specific definitions of coordination parameters (initiation, leadership, followership, termination), 2) differentiation between coordination research on individuallevel process and group-level outcome, 3) analyses of collective action processes including initiation and termination, and 4) operationalization of successful group
\end{abstract}

L. W. Pyritz $(\bowtie) \cdot$ C. Fichtel

Behavioral Ecology \& Sociobiology Unit, German Primate Center; and CRC Evolution of Social Behaviour, University of Göttingen, 37077 Göttingen, Germany

e-mail: LennartPyritz@gmx.net

\section{A. J. King}

Structure \& Motion Laboratory, Royal Veterinary College, University of London, Hertfordshire AL9 7DY, UK

\section{Sueur}

Primate Research Institute, Kyoto University, Inuyama 484-8506 Aichi, Japan

C. Sueur

Unit of Social Ecology, Free University of Brussels, 1050 Brussels, Belgium 
movements in the field to collect meaningful and comparable data across different species.

Keywords Animal groups $\cdot$ Coordination $\cdot$ Decision-making $\cdot$ Terminology

\section{Introduction}

The number of studies on group coordination, leadership, and decision-making in humans and nonhuman primates has increased considerably during the last decade (Conradt and Roper 2005; Conradt and List 2009; Fichtel et al. 2011; King et al. 2009; Petit and Bon 2010). However, integration of results from different studies has been impeded by ambiguous terminology and conceptual/methodological shortcomings (see Jacobs 2010; Petit and Bon 2010; Pyritz et al. 2010 for recent discussions). We discussed these inconsistencies with participants during the symposium "Where next? Coordination and decision-making in primate groups" at the XXIIIth Congress of the International Primatological Society (IPS) at Kyoto, Japan, in September 2010. As a result of the strong positive feedback, we decided to initiate a public discussion about these terms via an interactive online platform joined by participants of the symposium and associated researchers. The glossary contained 20 central terms regarding coordination and decision-making research, most of which were previously compiled in a comprehensive review by Conradt and Roper (2005). Each participant had the opportunity to contribute additional terms, definitions, references, and commentaries. Table I provides the final glossary based on the summary of all entries. In addition, we identified a number of conceptual and methodological issues that have been discussed rarely or controversially in the literature so far. We here discuss the most debated terms of the glossary and a number of crucial conceptual issues in more detail.

\section{Terminology}

\section{Combined Decisions}

Conradt and Roper (2005) defined a "combined decision" as the sum of individual group members' decisions that — unintentionally - affects the group as a whole (Table I). However, this definition is ambiguous and cannot be separated clearly from the often used and well established term "quorum decisions," in which group members also choose individually between different options until a certain threshold is reached that affects the entire group (Seeley et al. 2006; Ward et al. 2008; Table I). In fact, the mechanisms of reaching a group decision employed in a large colony of ants (Leptothorax albipennis) choosing between several new nest sites (Franks et al. 2002) are principally the same as those employed by Tonkean macaques (Macaca tonkeana) in a predeparture quorum (Sueur et al. 2010) or meerkats (Suricata suricatta) increasing travel speed via a vocal voting mechanism (Bousquet et al. 2010). In these species, each group member decides individually where and when to move, even if this decision is influenced by the behaviors of conspecifics. Further, 
Table I Central terms of coordination and decision-making research and their respective definitions, selected references, and commentaries compiled by participants of the XXIIIth Congress of the International Primatological Society (IPS) in Kyoto, Japan

\begin{tabular}{|c|c|c|c|}
\hline Term & Definition & References (selection) & Comments \\
\hline $\begin{array}{r}\text { Combined } \\
\text { decision }\end{array}$ & $\begin{array}{l}\text { Members of a group choose } \\
\text { individually (but not } \\
\text { necessarily independently) } \\
\text { between } \geq 2 \text { actions. They } \\
\text { do not aim for consensus, } \\
\text { but the combined result of } \\
\text { their decisions usually } \\
\text { affects the group as a whole. }\end{array}$ & Conradt and Roper 2005 & $\begin{array}{l}\text { The distinction between a } \\
\text { quorum threshold, e.g., in } \\
\text { ants or Tonkean macaques, } \\
\text { and a combined decision } \\
\text { seems inconclusive. See } \\
\text { text for detailed discussion. }\end{array}$ \\
\hline $\begin{array}{c}\text { Consensus } \\
\text { decision }\end{array}$ & $\begin{array}{l}\text { Group members choose } \\
\text { between } \geq 2 \text { mutually } \\
\text { exclusive actions to } \\
\text { reach a consensus on } \\
\text { the group level. }\end{array}$ & $\begin{array}{l}\text { Conradt and Roper 2005; } \\
\text { King et al. 2008; Sueur } \\
\text { and Petit 2008a,b }\end{array}$ & \\
\hline $\begin{array}{l}\text { Consistent } \\
\text { leadership }\end{array}$ & $\begin{array}{l}\text { The same individual always } \\
\text { leads group actions. }\end{array}$ & Conradt and Roper 2005 & $\begin{array}{l}\text { Opposite of distributed/ } \\
\text { variable leadership. }\end{array}$ \\
\hline $\begin{array}{l}\text { Democratic and } \\
\text { despotic }\end{array}$ & $\begin{array}{l}\text { A consensus may be reached } \\
\text { by the averaging of } \\
\text { preferences (democracy), } \\
\text { or by following the choices } \\
\text { of specific leaders } \\
\text { (despotism). } \\
\text { Democratic=shared decision- } \\
\text { making; despotic=unshared } \\
\text { decision-making. }\end{array}$ & $\begin{array}{l}\text { King et al. 2008; King } \\
\text { and Cowlishaw } 2009\end{array}$ & $\begin{array}{l}\text { In primatology, we usually } \\
\text { use "despotic" and } \\
\text { "egalitarian" (or "tolerant") } \\
\text { to characterize the social } \\
\text { system of a species and } \\
\text { "shared" or "unshared" to } \\
\text { describe consensus } \\
\text { decisions. See text for } \\
\text { detailed discussion. }\end{array}$ \\
\hline Follower & $\begin{array}{l}\text { An individual that follows/ } \\
\text { joins the initiator/leader } \\
\text { for a certain activity. }\end{array}$ & $\begin{array}{l}\text { Jacobs et al. 2008; Pyritz } \\
\text { et al. 2010; Ramseyer } \\
\text { et al. 2009a, b, c; Sueur } \\
\text { and Petit 2008a,b }\end{array}$ & $\begin{array}{l}\text { The definition of a follower } \\
\text { (of a group movement) } \\
\text { should be operational and } \\
\text { taxon-specific. See text for } \\
\text { discussion. }\end{array}$ \\
\hline $\begin{array}{l}\text { Hidden } \\
\text { leadership }\end{array}$ & $\begin{array}{l}\text { The same individual initiates } \\
\text { and terminates a group } \\
\text { activity (movement), } \\
\text { although } \\
\text { it is not guiding the } \\
\text { movement in front of } \\
\text { the group. }\end{array}$ & $\begin{array}{l}\text { Kummer 1968; } \\
\text { Pyritz et al. } 2010\end{array}$ & $\begin{array}{l}\text { The new definition of a } \\
\text { leader (see below) includes } \\
\text { hidden leadership. Therefore, } \\
\text { we no longer need this term. }\end{array}$ \\
\hline Initiator & $\begin{array}{l}\text { The group member that } \\
\text { initiates a group activity. }\end{array}$ & $\begin{array}{l}\text { Bourjade and Sueur 2010; } \\
\text { Jacobs et al. 2008; Pyritz } \\
\text { et al. 2010; Ramseyer et al. } \\
\text { 2009a, b, c; Sueur and } \\
\text { Petit 2008a,b; }\end{array}$ & $\begin{array}{l}\text { The definition of an initiator } \\
\text { (of a group movement) } \\
\text { should be operational and } \\
\text { taxon-specific. See text for } \\
\text { discussion. }\end{array}$ \\
\hline Leader & $\begin{array}{l}\text { Individual eliciting follower } \\
\text { behavior/exerting social } \\
\text { influence on others, by its } \\
\text { rank into the progression, } \\
\text { its behavior, or its social } \\
\text { status. }\end{array}$ & $\begin{array}{l}\text { Harcourt et al. 2009; } \\
\text { King 2010; Petit and } \\
\text { Bon 2010; Pillot et al. } \\
\text { 2010; Sueur and Petit } \\
\text { 2008a,b, } 2010\end{array}$ & $\begin{array}{l}\text { The definition of a leader } \\
\text { should not be restricted } \\
\text { by the spatial position } \\
\text { during a group movement } \\
\text { (Kummer 1968) but } \\
\text { comprise the whole process } \\
\text { of a collective action. It is } \\
\text { also a defining characteristic } \\
\text { of a leader that he exerts } \\
\text { social influence on } \\
\text { conspecifics. See text for } \\
\text { detailed discussion. }\end{array}$ \\
\hline Mimetism & $\begin{array}{l}\text { The probability that an } \\
\text { individual performs a } \\
\text { behavior depends on }\end{array}$ & $\begin{array}{l}\text { Camazine et al. 2001; } \\
\text { Deneubourg and Goss } \\
\text { 1989; Meunier } \text { et al. 2006; }\end{array}$ & \\
\hline
\end{tabular}


Table I (continued)

\begin{tabular}{|c|c|c|c|}
\hline Term & Definition & References (selection) & Comments \\
\hline & $\begin{array}{l}\text { the number of individuals } \\
\text { already performing this } \\
\text { behavior (anonymous } \\
\text { mimetism, allelomimetism). } \\
\text { It can also depend on the } \\
\text { social relationships the } \\
\text { individual has with group } \\
\text { members already displaying } \\
\text { the behavior (selective } \\
\text { mimetism). }\end{array}$ & $\begin{array}{l}\text { Petit et al. 2009; } \\
\text { Sueur et al. } 2009 \text {; } \\
\text { Sumpter } 2006\end{array}$ & \\
\hline Overtaking & $\begin{array}{l}\text { Followers overtake the } \\
\text { individual } \\
\text { at the forefront of the group } \\
\text { without diverging }>45^{\circ} \\
\text { from the initial trajectory. }\end{array}$ & $\begin{array}{l}\text { Boinski 1991; Erhart } \\
\text { and Overdorff } 1999 ; \\
\text { Pyritz et al. } 2010 ; \\
\text { Trillmich et al. } 2004\end{array}$ & \\
\hline $\begin{array}{c}\text { Predeparture } \\
\text { behavior }\end{array}$ & $\begin{array}{l}\text { Behavior performed before } \\
\text { the departure of the initiator, } \\
\text { making the timing of the } \\
\text { departure predictable and } \\
\text { potentially indicating the } \\
\text { direction in which } \\
\text { individuals want to move. }\end{array}$ & $\begin{array}{l}\text { Bourjade and Sueur } \\
\text { 2010; Sueur and } \\
\text { Petit 2008a,b }\end{array}$ & $\begin{array}{l}\text { Other names: preliminary } \\
\text { behavior, notifying } \\
\text { behavior, voting } \\
\text { behavior, intention } \\
\text { movement, priming } \\
\text { behavior. }\end{array}$ \\
\hline $\begin{array}{l}\text { Predeparture } \\
\text { period }\end{array}$ & $\begin{array}{l}\text { Period preceding the departure } \\
\text { of the initiator and delineated } \\
\text { by the presence of } \\
\text { predeparture behaviors. }\end{array}$ & $\begin{array}{l}\text { Bourjade and Sueur } \\
\text { 2010; Sueur and } \\
\text { Petit 2008a,b }\end{array}$ & $\begin{array}{l}\text { Other names: } \\
\text { preliminary period. }\end{array}$ \\
\hline Quorum & $\begin{array}{l}\text { Minimum number, i.e., } \\
\text { threshold, of group members } \\
\text { that need to take or favor a } \\
\text { particular action for the } \\
\text { whole group to adopt } \\
\text { this action. }\end{array}$ & $\begin{array}{l}\text { Bousquet et al. 2010; } \\
\text { Franks et al. 2002; } \\
\text { Seeley et al. 2006; } \\
\text { Sueur et al. 2010; } \\
\text { Ward et al. 2008; }\end{array}$ & $\begin{array}{l}\text { In principle, the quorum } \\
\text { could be a majority, } \\
\text { submajority (less than a } \\
\text { majority), or supermajority } \\
\text { (more than a majority) of } \\
\text { members. In practice, } \\
\text { animals are likely to } \\
\text { determine whether a } \\
\text { quorum has been reached } \\
\text { by estimating the relative } \\
\text { numerousness of members } \\
\text { contributing to the quorum, } \\
\text { often by relying on } \\
\text { indirect cues. }\end{array}$ \\
\hline
\end{tabular}

$\begin{array}{cl}\begin{array}{c}\text { Recruitment } \\ \text { behavior }\end{array} & \begin{array}{c}\text { Behavior that increases the } \\ \text { probability that other } \\ \text { group members will join a } \\ \text { certain activity. It results } \\ \text { in a larger number of joiners } \\ \text { or in quicker joining of the } \\ \text { collective action than } \\ \text { when not performed. }\end{array} \\ \text { Self-organizing } & \begin{array}{l}\text { Individual group members } \\ \text { follow local behavioral } \\ \text { system }\end{array} \\ & \begin{array}{l}\text { rules, resulting in } \\ \text { organized behavior by the } \\ \text { whole group without the } \\ \text { need for global control. }\end{array}\end{array}$

Shared consensus decision
Bourjade and

Sueur 2010

Camazine et al. 2001;

Conradt and Roper 2005;

Couzin et al. 2002;

Sueur et al. 2009
Emergent properties due to the interactions between individuals in self-organized systems are more complex than the emergent properties that should be observed by the sum of individual behaviors.

Opposite of unshared consensus decision. 
Table I (continued)

\begin{tabular}{|c|c|c|c|}
\hline Term & Definition & References (selection) & Comments \\
\hline & $\begin{array}{l}\text { decision outcome. The } \\
\text { consensus is usually } \\
\text { determined by a quorum } \\
\text { or by averaging over } \\
\text { all votes. }\end{array}$ & & \\
\hline Terminator & $\begin{array}{l}\text { Individual that stops and } \\
\text { seems to suggest the } \\
\text { termination of a group } \\
\text { movement. }\end{array}$ & Pyritz et al. 2010 & $\begin{array}{l}\text { Group movements can } \\
\text { feasibly comprise } 2 \text { linked } \\
\text { decisions: 1) initiation: } \\
\text { when and in which } \\
\text { direction to move and 2) } \\
\text { termination: when and } \\
\text { where to stop See text } \\
\text { for detailed discussion. }\end{array}$ \\
\hline $\begin{array}{l}\text { Unshared } \\
\text { consensus } \\
\text { decision }\end{array}$ & $\begin{array}{l}\text { One particular group member, } \\
\text { e.g., the dominant, makes } \\
\text { the decision on behalf of all } \\
\text { group members. All other } \\
\text { members abide by this } \\
\text { decision. }\end{array}$ & $\begin{array}{l}\text { Conradt and Roper 2005; } \\
\text { Sueur and Petit 2008a,b }\end{array}$ & $\begin{array}{l}\text { Opposite of shared } \\
\text { consensus decision. }\end{array}$ \\
\hline $\begin{array}{l}\text { Variable/ } \\
\text { distributed } \\
\text { leadership }\end{array}$ & $\begin{array}{l}\text { Different group members } \\
\text { lead group actions on } \\
\text { different occasions. }\end{array}$ & $\begin{array}{l}\text { Conradt and Roper 2005; } \\
\text { Jacobs et al. 2008; } \\
\text { Petit and Bon } 2010\end{array}$ & $\begin{array}{l}\text { Opposite of consistent } \\
\text { leadership. }\end{array}$ \\
\hline Voting & $\begin{array}{l}\text { An individual communicates } \\
\text { its individual preference } \\
\text { with regard to the } \\
\text { decision outcome. }\end{array}$ & $\begin{array}{l}\text { Bousquet et al. 2010; } \\
\text { Prins 1996; Sellers } \\
\text { et al. 2007; Sueur } \\
\text { et al. } 2010\end{array}$ & \\
\hline
\end{tabular}

there is no easy way to test whether individuals aim to reach a group consensus, which was the criterion Conradt and Roper (2005) used to distinguish consensus decisions from combined decisions. We therefore recommend not using the term "combined decision" in future research.

\section{Democratic and Despotic Decisions}

Researchers have used the terms "democratic" and "despotic" interchangeably with "shared" and "unshared" in a number of recent studies on decision-making (Conradt and Roper 2003; King et al. 2008; King and Cowlishaw 2009). "Democracy" describes a consensus reached by the majority principle, whereas "despotism" characterizes a consensus reached by following the choices of specific leaders in these studies. However, in primatology the term "despotic" is also used to characterize the social structure of a species, opposed to "egalitarian" or "tolerant" societies (Matsumura 1999), and the social structure of a species undoubtedly influences the process and outcome of consensus decision-making. For instance, Sueur and colleagues studied the decisions of 2 macaque species, with contrasting social structures, beginning a group movement after a resting period (Sueur and Petit 2008a,b). They found that egalitarian Tonkean macaques displayed an equally shared consensus whereas more despotic rhesus macaques (Macaca mulatta) displayed a partially shared consensus. These differences were attributable to the fact that in the despotic rhesus macaques, dominant individuals 
had a disproportionate influence on the movement decisions of group-mates: they were followed more often than the lower-ranked individuals. In contrast, all individuals in the more egalitarian Tonkean macaques had a similar influence on one another's decisions to move and the decision was equally shared. However, the social structure of a primate group can more broadly be viewed as both the cause and consequence, reinforced via a feedback loop, of social interactions such as intensity of aggression, grooming, or reconciliatory patterns. These social interactions may be independent of group level decision-making processes. Thus, so as to not confound characteristics of the social system and collective decision-making in a group or causal relationships between these 2 realms, we suggest that future decision-making research should use only the terms "shared" and "unshared," and not "democratic" and "despotic."

\section{Leadership}

The definition of a leader should not be restricted to its spatial position during a group movement because individuals may also lead from behind, i.e., initiate and terminate a movement without being at the forefront of the group (Kummer 1968; called "hidden leadership" in Pyritz et al. 2010). Instead, a leader should be defined as an individual that elicits follower behavior (from a majority of or all group members) and exerts social influence on group members either by its rank, experience, social status/connectedness, or specific behavior (King 2010; Petit and Bon 2010; Sueur and Petit 2008b). Further, an individual that leads may not do so intentionally, i.e., leadership can be a passive process (Fischer and Zinner 2011; King et al. 2009; King and Sueur 2011). For instance, in sheep (Ovis aries), individuals triggered follower behavior by merely moving away from their group following a sound they had been trained to, thus eliciting group movements as incidental leaders (Pillot et al. 2010).

\section{Concepts and Methods}

\section{Taxon-Specific Definitions}

It remains a major practical challenge for human observers to identify reliably and define operationally a group movement in the field. The following is the most detailed definition employed in recent studies on the coordination of group movements in different species: An individual moves a certain distance toward the edge of the group either in a defined time period, e.g., $10 \mathrm{~m}$ within $40 \mathrm{~s}$ (Leca et al. 2003; Stueckle and Zinner 2008; Sueur and Petit 2008a,b), or without stopping and feeding (Bourjade et al. 2009; Ramseyer et al. 2009a, b, c), and is followed by a certain number of group members. However, even in this fairly detailed definition, most parameters were not assessed empirically. In fact, a definition of group movements must account for a number of taxon-specific characteristics such as different traveling types (directed movements vs. "feed-as-you-go," ameboid-like movements that do not necessarily require an initiator or coordination among group members, e.g., bonobos [Pan paniscus]: Wrangham 2000); mean travel distances; 
ecological conditions (resource abundance, predation risk); as well as the size, composition, and cohesion of the group. Therefore, we encourage the use of operational group movement definitions for different taxa that are built upon empirical data collected before the study period used for the analyses of group movements. In the long term, these empirical details will generate a comprehensive database for multiple species and different contexts. Researchers will then be able to compare and contrast the results to see if general patterns are shared among different species. For practical details of how to operationalize definitions see Trillmich et al. (2004) and Pyritz et al. (2010).

\section{Individual-Level Process and Group-Level Outcome}

Studies of group coordination and decision-making examine 2 different levels that should be clearly distinguished. First, studies can focus on the group level, i.e., the question of whether there is consistent or variable leadership among several group movements or other collective actions (Erhart and Overdorff 1999; Jacobs et al. 2008; King et al. 2008; Pyritz et al. 2011). Second, studies can focus on the level of single movements and study the process, i.e., the question of whether decisions are shared or unshared and if they are mediated by mimetism, affiliative/genetic network relations, quorum thresholds, or self-organized processes (King and Sueur 2011; Petit and Bon 2010; Sueur and Petit 2008a,b, 2010; Sueur et al. 2009). It is important to separate these levels and clearly highlight the level at which the research is focused. King and Sueur (2011) and Sueur and Deneubourg (2011) explain how a consistent leadership or a consistent order of individuals could be observed even though the decision process is shared. For example, imagine $n \%$ of group members have to follow the first-moving individual, i.e., initiator, within $n$ minutes for a group movement to occur; otherwise the initiator stops moving and the whole group remains stationary. A study observing movement patterns during departure would conclude that the process is shared because multiple individuals contribute to the decision of the group to move. Researchers who observed only the order of departure when the group chose to move would observe group movements that were always led by the same individuals, and the decision appears unshared. Because the outcome at the group level, i.e., departure order, is easier to observe, it is no surprise that most early studies in the area of coordination focused on who leads (King 2010). However, identifying who leads may not tell the whole story. For instance, an individual can always, or in most cases, be the leader of a group because his energetic reserves are always the first to be depleted, and he has to move to feed, but might have the same, or at least no stronger, influence on the joining process as other group members, e.g., in the case of an anonymous mimetism. In fact, a number of recent findings, e.g., macaques (Sueur and Petit 2008a,b, 2010; Sueur et al. 2009), and horses (Bourjade et al. 2009) suggest shared consensus between group members at the movement level, even though a single leader or a few leaders, i.e., an unshared consensus with consistent leadership, has previously been reported, e.g., macaques (Reinhardt et al. 1987) and horses (Feist and Mc Cullough 1976). For a further discussion of this topic see Bourjade and Sueur (2010). 
Initiation and Termination of Collective Actions

During the course of a group movement, animals have to make 2 basic decisions, 1) initiation: when and in which direction to move and 2) termination: when and where to stop. Theoretically, the decision where to stop may be a second consensus decision independent from the decision during initiation, and the 2 decisions can be initiated by the same or different leaders (Boinski 1991; Erhart and Overdorff 1999; Pyritz et al. 2010). Although this issue has been addressed rarely, it yields important implications for the decision type, i.e., there could be unshared decision-making at departure that is mitigated by individuals overtaking the initial leader and terminating the movement, resulting in a shared decision-making with regard to the whole movement process. Accordingly, we suggest making a distinction between these 2 events and exploring the consistency of leadership during travel. For instance, one might classify leadership as "stable," i.e., the initiator leads the movement until termination, or "unstable," i.e., the terminator is different from the initiator (Pyritz et al. 2011). In general, it is important to study the entire process of group movements from initiation to termination to gain a realistic image of coordination, leadership, and decision-making in a given species (Fichtel et al. 2011; Pyritz et al. 2010; Trillmich et al. 2004). Indeed, such detail will be crucial if we are to determine the temporal scale over which decisions are made, and outcomes occur. Take an example where the same individual, $X$, both initiates and terminates the movement. This could imply that 1) X made the decision to move and the decision to stop, which was followed by group-mates, or 2) X made the decision to move in a particular direction of travel (Noser and Byrne 2007; Sueur et al. 2010) in a "goal-directed fashion" toward a particular destination, and was first to arrive, but did not make the decision to terminate the movement, because all group-mates that followed were aware of the target destination at the initiation (Pyritz et al. in prep.). In other words, the decision of where to terminate had been made at the initiation.

\section{Successful Group Movements}

Early studies set a threshold of 50\% of group members having to follow an initiator, within a certain time frame, to consider a movement as successful (Erhart and Overdorff 1999). More recent studies considered an initiation attempt as failed only if no individual followed (Jacobs et al. 2008; Sueur and Petit 2008a; Trillmich et al. 2004). However, the mean number of followers that determines a successful group movement is presumably taxon-specific and may change with ecological season or resource abundance (King et al. 2008; Pyritz et al. 2011). Further, fission into subgroups - and an accordingly lower number of followers for single initiatorsmay represent the most beneficial group decision under certain conditions (Jacobs 2010; Kerth 2010). Hence, it is difficult to provide a general definition for successful or unsuccessful movements. We suggest giving a taxon- (and season-) specific threshold of success regarding followers below which the initiator does not stop and show recruitment behavior (Table I), or "give-up" on the movement entirely, e.g., 5 followers in chacma baboons (Papio hamadryas: Stueckle and Zinner 2008); 3 followers in Verreaux's sifakas (Propithecus verreauxis: Trillmich et al. 2004), 
white-faced capuchins (Cebus capucinus: Petit et al. 2009), meerkats (Suricata suricatta: Bousquet et al. 2010), and Tonkean macaques (Sueur and Petit 2010). Combining this with operational group movement definitions for different taxa, it may be possible to uncover a common threshold - a universal - to primate group movements. In fact, examination of the aforementioned studies indicates that a threshold of approximately 3 followers seems to be sufficient to elicit a group movement, whatever the species. This number may provide sufficient protection against predators or enough collective knowledge to orientate within the home range and detect resources, for example.

\section{Conclusion}

After a public discussion about terms used in coordination and decision-making research via an interactive online platform, we have come to a number of conclusions that will aid future research on this topic. First, we highlighted a number of ambiguous terms ("combined decision"; "despotic/democratic decision") and suggested that these not be used in future coordination research. We also suggest maintaining the terms "leader" and "leadership" because although they can sometimes be ambiguous, as long as an operational definition is provided these terms are useful to broader scientific communication and integration (King 2010; Pyritz et al. 2010). Further, we discussed a number of conceptual issues: group vs. movement level; operationalized successful group movements; collective action process including initiation and termination. Ultimately, the implementation of our suggestions should provide comparable data on coordination and decision-making in different species and facilitate the identification of general patterns that are shared among different taxa.

Acknowledgments We thank the participants of the symposium "Where next? Coordination and decision making in primate groups" at the XXIIIth Congress of the International Primatological Society (IPS) for valuable discussions and comments on the glossary and conceptual issues. Henning Lahmann kindly implemented the online glossary. We also thank Joanna Setchell and the International Journal of Primatology for providing financial support and making this special issue possible. L. W. Pyritz is funded by the German Research Foundation (DFG: KA 1082/16-1), A. J. King by a NERC Postdoctoral Fellowship (NE/H016600/2), and C. Sueur by the Japan Society for the Promotion of Science. Joanna Setchell and 2 anonymous reviewers provided valuable comments on the manuscript.

Open Access This article is distributed under the terms of the Creative Commons Attribution Noncommercial License which permits any noncommercial use, distribution, and reproduction in any medium, provided the original author(s) and source are credited.

\section{References}

Boinski, S. (1991). The coordination of spatial position: A field study of the vocal behaviour of adult female squirrel monkeys. Animal Behaviour, 41, 89-102.

Bourjade, M., \& Sueur, C. (2010). Shared or unshared consensus to move collectively? Towards methodological concerns. Behavioural Processes, 84, 648-652.

Bourjade, M., Thierry, B., Maumy, M., \& Petit, O. (2009). Decision-making in Przewalski horses (Equus ferus przewalskii) is driven by the ecological contexts of collective movements. Ethology, 115, 321-330. 
Bousquet, C. A. H., Sumpter, D. J. T., \& Manser, M. B. (2010). Moving calls: A vocal mechanism underlying quorum decisions in cohesive groups. Proceedings of the Royal Society of London. Series B: Biological Sciences. doi:10.1098/rspb.2010.1739.

Camazine, S., Deneubourg, J. L., Franks, N. R., Sneyd, J., Theraulaz, G., \& Bonabeau, E. (2001). Selforganization in biological systems. Princeton, NJ: Princeton University Press.

Conradt, L., \& Roper, T. J. (2003). Group decision-making in animals. Nature, 421, 155-158.

Conradt, L., \& Roper, T. J. (2005). Consensus decision making in animals. Trends in Ecology \& Evolution, 20, 449-456.

Conradt, L., \& List, C. (2009). Introduction. Group decisions in humans and animals: A survey. Proceedings of the Royal Society of London. Series B: Biological Sciences, 364, 719-742.

Couzin, I. D., Krause, J., James, R., Ruxton, G. D., \& Franks, N. R. (2002). Collective memory and spatial sorting in animal groups. Journal of Theoretical Biology, 218, 1-11.

Deneubourg, J. L., \& Goss, S. (1989). Collective patterns and decision-making. Ethology, Ecology and Evolution, 1, 295-311.

Erhart, E. M., \& Overdorff, D. J. (1999). Female coordination of group travel in wild Propithecus and Eulemur. International Journal of Primatology, 20, 927-941.

Feist, J. D., \& Mc Cullough, D. R. (1976). Behaviour patterns and communication in feral horses. Zeitschrift für Tierpsychologie, 41, 337-371.

Fichtel, C., Pyritz, L., \& Kappeler, P. M. (2011). Coordination of group movements in non-human primates. In M. Boos, M. Kolbe, S. Ellwart, \& P. M. Kappeler (Eds.), Coordination in human and non-human primate groups (pp. 37-56). Heidelberg, Berlin: Springer.

Fischer, J., \& Zinner, D. (2011). Communication and cognition in primate group movement. International Journal of Primatology, 32

Franks, N. R., Pratt, S. C., Mallon, E. B., Britton, N. F., \& Sumpter, D. J. T. (2002). Information flow, opinion polling and collective intelligence in house-hunting social insects. Philosophical Transactions of the Royal Society B: Biological Sciences, 357, 1567-1583.

Harcourt, J. L., Ang, T. Z., Sweetman, G., Johnstone, R. A., \& Manica, A. (2009). Social feedback and the emergence of leaders and followers. Current Biology, 19, 248-252.

Jacobs, A. (2010). Group cohesiveness during collective movements: Travelling apart together. Behavioural Processes, 84, 678-680.

Jacobs, A., Maumy, M., \& Petit, O. (2008). The influence of social organisation on leadership in brown lemurs (Eulemur fulvus fulvus) in a controlled environment. Behavioural Processes, 79, 111-113.

Kerth, G. (2010). Group decision-making in fission-fusion societies. Behavioural Processes, 84, 662-663.

King, A. J. (2010). Follow me! I'm a leader if you do; I'm a failed initiator if you don't. Behavioural Processes, 84, 671-674.

King, A. J., \& Cowlishaw, G. (2009). Leaders, followers and group decision-making. Communicative and Integrative Biology, 2, 147-150.

King, A. J., \& Sueur, C. (2011). Where next? Group coordination and collective decision-making by primates. International Journal of Primatology, 32

King, A. J., Douglas, C. M. S., Huchard, E., Isaac, N. J. B., \& Cowlishaw, G. (2008). Dominance and affiliation mediate despotism in a social primate. Current Biology, 18, 1833-1838.

King, A. J., Johnson, D. D. P., \& Van Vugt, M. (2009). The origins and evolution of leadership. Current Biology, 19, 911-916.

Kummer, H. (1968). The coordination of travel. In Social organization of hamadryas baboons: A field study (pp. 122-156). Chicago: University of Chicago Press.

Leca, J. B., Gunst, N., Thierry, B., \& Petit, O. (2003). Distributed leadership in semi-free ranging whitefaced capuchin monkeys. Animal Behaviour, 66, 1045-1052.

Matsumura, S. (1999). The evolution of "egalitarian" and "despotic" social systems among macaques. Primates, 40, 23-31.

Meunier, H., Leca, J. B., Deneubourg, J. L., \& Petit, O. (2006). Group movement decisions in capuchin monkeys: The utility of an experimental study and a mathematical model to explore the relationship between individual and collective behaviours. Behaviour, 143, 1511-1527.

Noser, R., \& Byrne, R. W. (2007). Travel routes and planning of visits to out-of-sight resources in wild chacma baboons (Papio ursinus). Animal Behaviour, 73, 257-266.

Petit, O., \& Bon, R. (2010). Decision-making processes: The case of collective movements. Behavioural Processes, 84, 635-647.

Petit, O., Gautrais, J., Leca, J. B., Theraulaz, G., \& Deneubourg, J. L. (2009). Collective decision-making in white-faced capuchins. Proceedings of the Royal Society of London. Series B: Biological Sciences, 276, 3495-3503. 
Pillot, M. H., Gautrais, J., Gouello, J., Michelena, P., Sibbald, A., \& Bon, R. (2010). Moving together: Incidental leaders and naïve followers. Behavioural Processes, 83, 235-241.

Prins, H. H. T. (1996). Ecology and behaviour of the African buffalo. London: Chapman and Hall.

Pyritz, L., Fichtel, C., \& Kappeler, P. (2010). Conceptual and methodological issues in the comparative study of collective group movements. Behavioural Processes, 84, 681-684.

Pyritz, L. et al. (2011). Coordination of group movements in wild red-fronted lemurs: Processes and influence of ecological and reproductive seasonality. International Journal of Primatology, 32

Ramseyer, A., Petit, O., \& Thierry, B. (2009a). Patterns of group movements in juvenile domestic geese. Journal of Ethology, 27, 369-375.

Ramseyer, A., Boissy, A., Dumont, B., \& Thierry, B. (2009b). Decision making in group departures of sheep is a continuous process. Animal Behaviour, 78, 71-78.

Ramseyer, A., Thierry, B., Boissy, A., \& Dumont, B. (2009c). Decision-making processes in group departures of cattle. Ethology, 115, 948-957.

Reinhardt, V., Reinhardt, A., \& Houser, D. (1987). Prompted progression order in a troop of captive rhesus monkeys. Folia Primatologica, 48, 121-124.

Seeley, T. D., Visscher, P. K., \& Passino, K. M. (2006). Group decision making in honey bee swarms. American Scientist, 94, 220-229.

Sellers, W. I., Hill, R. A., \& Logan, B. S. (2007). An agent-based model of group decision making in baboons. Philosophical Transactions of the Royal Society of London. Series B: Biological Sciences, 362, 1699-1710.

Stueckle, S., \& Zinner, D. (2008). To follow or not to follow: Decision making and leadership during the morning departure in chacma baboons. Animal Behaviour, 75, 1995-2004.

Sueur, C., \& Petit, O. (2008a). Shared or unshared consensus decision in macaques? Behavioural Processes, 78, 84-92.

Sueur, C., \& Petit, O. (2008b). Organization of group members at departure is driven by social structure in Macaca. International Journal of Primatology, 29, 1085-1098.

Sueur, C., \& Petit, O. (2010). Signals use by leaders in Macaca tonkeana and Macaca mulatta: Groupmate recruitment and behaviour monitoring. Animal Cognition, 13, 239-248.

Sueur, C., \& Deneubourg, J-L. (2011). Self-organization in primates: Understanding the rules underlying collective movements. International Journal of Primatology, 32

Sueur, C., Petit, O., \& Deneubourg, J. L. (2009). Selective mimetism at departure in collective movements of Macaca tonkeana: An experimental and theoretical combination of mimetic rules in macaques. Animal Behaviour, 78, 1087-1095.

Sueur, C., Deneubourg, J.-L., \& Petit, O. (2010). From the first intention movement to the last joiner: Macaques combine mimetic rules to optimize their collective decisions. Proceedings of the Royal Society of London. Series B: Biological Sciences. doi:10.1098/rspb.2010.2084.

Sumpter, D. J. (2006). The principles of collective animal behaviour. Philosophical Transactions of the Royal Society of London. Series B: Biological Sciences, 361, 5-22.

Trillmich, J., Fichtel, C., \& Kappeler, P. M. (2004). Coordination of group movements in wild Verreux`s sifakas (Propithecus verreauxi). Behaviour, 141, 1103-1120.

Ward, A. J. W., Sumpter, D. J. T., Couzin, I. D., Hart, P. J. B., \& Krause, J. (2008). Quorum decisionmaking facilitates information transfer in fish shoals. Proceedings of the National Academy of Sciences of the United States of America, 105, 6948-6953.

Wrangham, R. W. (2000). Why are male chimpanzees more gregarious than mothers? A scramble competition hypothesis. In P. M. Kappeler (Ed.), Primate males. Causes and consequences of variation in group composition (pp. 248-258). Cambridge: Cambridge University Press. 